\title{
Swearing in Bengkulu-Malay Language with the Animals as Reference
}

\author{
Eli Rustinar \\ Universitas Muhammadiyah Bengkulu \\ elirustinar@umb.ac.id / elirustinar@ymail.com
}

\begin{abstract}
The utterance which contained swear sometimes was not realized its existence because of its spontaneous characteristic. This communication event could lead to the misappropriation of meaning because the meaning of a swearing word sometimes was applied to the reference which was probably not in accordance to the real meaning itself, for example swearing with the animals as reference. In Bengkulu-Malay language, when the person swore, there would be a reference to the nature of the animals that was said as if similar to the human nature that was swore to the imposition of human characteristics in animals. The researcher used the eclectic approach to decide the theory, methodology, and explaining the result of the research with the aim to complete each other. The method of this research was descriptive qualitative. The location of the research was done during the process event of communication. The data was the swears which referred to the animals. The sources of the data was taken from the informant (speaker of Bengkulu-Malay Language) who were not specified (accidental sampling). It meant whoever accidentally met with the researcher could be used as an informant in accordance with the purpose of research. The method of collecting the data was done by using the refer and introspection methods. The refer method in data collection technique was done with the tapping and recording techniques. Meanwhile the introspection method was done with the study method technique of collecting data using equivalent referential. The result of the research shown that there were five (5) kinds of swear which referred to the animals, they were: (1) bangsat (bedbugs); (2) anjing (dogs); (3) babi (pigs); (4) cak ikan buntal (puffer fish); and (5) kucing air (beaver); (6) lolak (sea shells); (7) badak (rhinoceros); and (8) bujuk (freshwater-fish with a very bad appearance).
\end{abstract}

Keywords: swear, animal reference, Bengkulu-Malay Language

\section{INTRODUCTION}

Language is an integral part of human life, because without language, human can not have the perfect social interaction. Language can also be viewed as a mirror of the personality of a human. It happens because the language is the reflection of sense, thought, and behaviour of its speaker. Through language, the human can interact and communicate with their fellows. Even more widely, it can be said that with the language, humans can show their identity or the special characteristic of certain society.

Everyone must have had an unexpected event. When it happens to their life, the various reaction will arise to the person who experiences it, such as the feeling of anger, hatred, disappointed, or upset to someone else. In this context, people who can not restrain their emotions often spontaneously speak out as a form of anger, hatred, disappointment, resentment by swearing.

Speaking as one of the main activities of humans in society has three things that must be considered as civilized people. They are politeness of the language, urbane of the language and ethics of the language (Chaer, 2010, p. vii). The politeness language refers to the using of language elements. The urbane language refers to the appropriate or inappropriate of the speech which is going to be spoken to the hearer, and the ethics language regards to the physical attitudes or behavior to express the utterance.

Swears can be analyzed as the worst mannered of the language because of its essential nature as a tool of expressing the lofty of a culture and also to build the harmonious relationship among people. Some of the experts who discuss about the politeness of the language such as Lakof (1972), Fraser (1978), Brown and Levinson (1978), and Lecch (1983) generally stated that there are three rules that must be obeyed so that the utterance produces the politeness of the language to the hearer. They are named as formalities, irresolution, and similarity or friendship.

Swears also can be seen in the opposite of a tool to build the harmonious relationship because actually it expresses many things which are not being favoured to the society themselves. Hence, from the swear itself, human can learn more about the culture of certain society in order to understand the way of their thought and to create better relationship with them. The language of the society also expresses swears through the unpleasant physical appearances, the objects under their circumstances, diseases and the nature of animals.

Swears according to (Ljung, 2011, p. 8) are the words which are not favoured to the society because of its function itself to express the emotions as the form of hatred, frustrated, obscene or surprise. According to (Dynel, 2012, p. 27) the words of swear are tend to be impolite because it contains the harsh words, cursed and swear itself.

The harsh words, swear and cursed themselves according to (Robin \& Mercury, 1995, p. 30, p. 295) must be restricted its use in public because of the politeness value in a society. On the other hand, according to (Salinger, 2002, 
p. 4, p. 22) Swears are the natural part of our language and undoubtedly is thought to be the efficient way to release the feeling of frustration, even some experts suggest to swear in order to reduce the stress level of a human.

According to Wijana (2004, p. 242) in addition to the used of the harsh words, swear and cursed as the impoliteness of the language, we as the speakers can use satire to express the utterance. The satire in the language is used to apply the politeness of the language to the hearers, then they will not feel embrassed. The speakers are tend to express their emotions of anger or cross by using the synonyms itself.

The utterance which contains swear sometimes is not realized its existence because of its spontaneous characteristic. Those events lead to the misappropriation of meaning because the meaning of some words which sometimes apply to the reference as the semantic analysis are inappropriate to the real meaning itself.

The event of communication which lead to the misappropriation of meaning in swearing in accordance to the opinion of (Suandi, 2014, p. 82) who stated that the utterance is not always as a direct representation to the element of its meaning. The swear exists in utterance because of its nature which is spontaneous leads to the misappropriation of the meaning. Because of the meaning itself in word of swears sometimes is applied to the reference which is not in accordance to the real meaning itself (lexical) for example the swear which takes animals as its reference.

The animals in an explanation of $(K B B I, 2018)$ are the animate creatures which are able to move and to give the reaction to the stimuli, but have no common sense. The common sense in this case is the healthy mind that comes from the word sense which is the power to think (to understand something) and mind which is the inner tool to guide the sense and feeling to determine the best and worst.

The animals are different from the human because human has common sense then the animal does not. In swearing of Bengkulu-Malay Language, the nature of human sometimes is described similar to the animals which is taken as the reference to the imposition of human characteristics in animals.

The study of meaning or semantic is the study of language usage in a language society to understand each other both lexical and contextual meanings (Leech, 1997, p. vii-viii), and according to Djajasudarma, (2016, p. 1-9) the contextual meaning relates to the references which explains a relation among words, the meaning, and the real world in finding the essence of the meaning by describing it based on the reference in the language usage in a society.

The reference to animals in swearing can be explained as the imposition of human to the other creature except human which is the animals. According to Kridalaksana (2008); KBBI, 2018) and Ullman (2012) and in swearing there is a possibility to pair the nature or behavior of the human to the animals. The form of the reference in animals only exist in certain characteristic of the animals which has similarity to the human or situation which is being the swear hearer. Not all of the animals can be used as the reference in swearing of Bengkulu-Malay Language.

The more clearly the meaning of the swear which is being understood by everyone, so the level of the anger of the swearer and the impact is being higher too. On the other hand, if the meaning of the swear is vague and it hardly can be understood by everyobe, so the level of the anger of the swearer and the impact is being lower too.

People who express swear (the swearer) are often considered negative (Oliver, 2011, p. 9). In line with that is the opinion of Dynel $(2012$, p. 27) who is stated that the words of swear are tend to be thought as the impolite words. In this context, the behavior of the language is considered negative because it is considered to violate social and cultural norms that are embedded in the community.

According to Fasya (2013, p. 81-82) through the social perspective can be expressed that swear is a tool to show the identity of the language user, and also to describe the social-condition of the society. Thus, swear in a language actually express several things or several behaviours which is being disliked by the society. Then from swearing, actually we can explore the culture of the society and know the way of their thinking. The language of the society can reveal the swear through the unusual appearance (physical), objects or things which are close to the environment of their life, actions and the nature of the animals, or the diseases that exist in their environment.

The principle of cooperation and politeness operates differently in a different culture and language of the society, in a different social-condition, in the different social classes and so on (Leech,1993, p. 15). Thus, swear in Bengkulu-Malay can not be separated from the used of language as the social phenomenal. According to the theory of Holmes $(2013$, p.1) stated that the way and the content of the utterance of the speaker can provide the clues about the speakers themselves, their origins, and their social level, with the reason that the same message can be understood differently to the different people. In the view of sociolinguistics, language is not only seen as an individual phenomenon but language is also a social symptom (Suandi, 2014:34). Its usage is not only determined by the language, but also the language of the society which used the same sign language system (Bloomfield, 1995, p. 29).

According to Holmes (2013) the social factors which influence the usage of language are: (1) age; (2) sex; (3) social status; and (4) the familiarity level. The age level of human can be divided into the language of children, teenagers, and adults. Sex in this case is whether the speaker is male or female. The social status regards to the occupation, education, and economy level which relates to the welfare of a human. The level of familiarity relates to the closeness of relations between the speaker and hearer.

The result of the research of Fasya (2013) shows that there is conformity to the theory of Holmes (2013, p. 158) which stated that the speaking behavior of female and male are different. The language of female speaker is 
considered as more polite and also own the higher politeness level than the male one. The usage of swear with the animals as the reference is tend to be used by the speaker in young-ages.

\section{METHODS}

The method which was used in this research was descriptive qualitative in order to describe and to study the meaning semantically based on the theory of (Djajasudarma \& Citraresmana, 2016, p. 1) which referred to the animals in Bengkulu-Malay Language. The location of this research was done during the event of communication which was a field research in Bengkulu. Based on the opinion of (Susiyanto, 2005, p. 133) said that the society of Bengkulu-Malay was not specifically settled in a certain areas in Bengkulu. The data of the research was the swearing with the animals as the reference which sources were taken from the informant (Bengkulu-Malay Speaker). They were chosen randomly for the sake of the research itself. Moreover there would be many things to be recorded if the informant which was as the sample was taken accidentally. So it was better for the researcher to take a big number of informant in order to get the objectivity of the research. Then, it could be called as the accidental sampling which was anyone who met with the researcher accidentally could be used as the informant in accordance to the aim of this research. (Martono, 2015, p. $318)$.

The method of collecting data research used refer and introspection methods. The refer method was done with the technique of collecting data in tapping technique by using the record player and record technique (Muhammad, 2011, p. 203-211) and (Mahsun, 2014, p. 92-93). The record technique was done on the data cards that would be provided. After the recording was done, the researcher performed a classification or grouping. The implementation of these two techniques was not absolutely sequential or flexible. The method of introspection used theory (Mahsun, 2014, p. 102-104) and (Muhammad, 2011, p. 215-217) namely the method of providing data by utilizing the linguistic intuition of the researchers who examine their mastered language (mother tongue) to provide the necessary data for analysis in accordance with the research objectives. The method of introspection was in the form of linguistic decision derived from native speakers, who possessed the linguistic competence in the target language, to check the validity of the data of the informant, if there was any doubtful data, it would be quickly recognized based on the language intuitions of the researcher, and according to (Djajasudarma \& Citraresmana, 2016, p. 214) the researcher used the introspection method to create the sentences by providing contexts to forms.

\section{FINDING AND DISCUSSION}

In Bengkulu-Malay Language, the researcher can find the swear which is expressed because of anger by using the harsh words with the abused aim and the satire words to reproach or to build the intimacy. The society of BengkuluMalay Language according to (Susiyanto, 2005, p. 217-221) have the characteristics of people living in the seashore which is hard. Because the stereotype of their living is hard and they speak as the way it is. But basically they have kind-heart and easygoing. The harshness of Bengkulu-Malay people is not same as rude, because the characteristic of their harshness is the stereotype of people in the seashore whose living is hard. They are not rude, even they are tend to be generous and open to everyone without seeing their origins.

The Malay spirit in the expression of the language has two main characteristics which are the factor of continuity and symbolic in expressing something commonly used by the people of Bengkulu (Trianto, 2004, pp. 191198) and this is the social forms which are determined by the polite society point of view about something that are allowed and are not allowed to be said (Ljung, 2011, p. 18). The statement above is strengthen by the opinion of (Susiyanto, 2005, p. 217-221) and (Kadir, 2004, p. 166) which stated that the Bengkulu-Malay society who is not rude is famous for poem in their daily life moreover in the custom ceremonial. Then they also have their living philosophy which hate conflict.

Those two language expression factors as the Malay spirit are not applied when the speaker is in anger because in Bengkulu-Malay Language, there is a nature or behavior of the speaker which is similar to the animals in swearing. The form of the reference to the animals is only for the certain characteristics of animals or situation which is being the swear target. Not all of the animals can be used as the reference of swears. The reference to animals in swearing can be explained as the imposition of human to the other creature except human which is the animals (Kridalaksana, 1993); (http://www.kbbi.web.id, 2018); and (Ullman, 2012).

The reference to the imposition of the characteristics of the human to the animals in the data found show that the swears point to the human characteristic in non-human creature and describe as the human characteristic to its subject itself. The reference to the animals in swearing whose function is to express the anger, hatred, disappointed, satire or intimacy and the human characteristic that imposed to the animals in swearing.

The result of the research shows that the researcher successfully found eight (8) swears which refer to the animals, they are:

(1). Bangsat pulo Bapak itu!, ,

bangsat pula Bapak itu! (What a bedbug that person is!)

(2). Woy, kluarlah dulu anjing ! 
Woy, keluarlah (da)hulu anjing!ee (Get out you dog!)

(3) Pai kau babi dari siko!

Pergi (eng)kau babi dari sini!ee (Go away you pig!)

(4) Hahaha... yo dak, lah cak ikan buntal naik ban...

Hahaha...yo dak sudah seperti ikan buntal naik ban (Hahaha, that person is like a puffer fish on a wheel)

(5) Nah, iko adonyo kucing air ko!. Kemaren orang ke rumahnyo...

Nah, ini adanya kucing air ini!. Kemarin orang ke rumahnya (There he is, the beaver! Yesterday, I

went to his house)

(6) Dasar mato lolak kau ko!.

Dasar mata lolak (eng)kau ini! (what a bad eye sea shell you are)

(7) Nyo memang muko badak!

Dia memang muka badak! (You truly have a face like a rhinoceros)

(8) Bujuk kau!

„Bujuk (eng)kau! (you are a bad fresh-water fish)

The nature or behavior of a person which is being paired to the land animals in swearing can be found in: (1) bangsat (bedbug), (2) anjing (dog), (3) babi (pig), and (7) badak (rhinoceros). The swears which refer to the sea animals are: (4) cak ikan buntal (puffer fish) and (6) lolak (seashell). The swears which refer to the fresh-water animals are: (5) kucing air (beaver) and (8) bujuk (fresh-water fish which has bad appearance).

The utterance bangsat is the form of swear in a word that refers to animals. Bangsat means ,bedbuge. It exists in data number (1) Bangsat pulo Bapak itu! (What a bedbug that person is!) is a swear which is uttered in anger and the sentence above uses the harsh word to the hearer whose character like a bedbug. The bedbug itself has a habit to drink the blood of human unwittingly and it can cause a health problem.

The next swearing words that refer to the animals is anjing (dog). This word is used because of the feeling of anger to the hearer. It can be found in the data number (2) Woy, kluarlah dulu anjing! (Get out you dog!). It is a swear that refers to the $d o g$ which is in the perception of Bengkulu-Malay Society is considered as the disgusting animals.

The swear refers to the animal babi (pig) is the word which is expressed the feeling of anger with the harsh word to the hearer whose character and behaviour is similar to the pig itself. It is clearly found in data number (3) Pai kau babi dari siko! (Go away you pig!). A pig is considered as the harmful and lazy animal. The use of the word 'pig' in the other swear phrase in Bengkulu-Malay language can be found in : Gilo babi kau ko "what a crazy pig you are" which means, getting angry uncertainlye and langkah gepuknyo kau kini, mecam babi alo "You have a very huge body like a pig ".

The other harsh phrases in swearing which refer to the animal badak (rhinoceros) can be found in data number (7) Nyo memang muko badak! (You truly have a face like a rhinoceros). It is used to show the character of a person who has no shame.

One of the liberating circumstances of being disappointed in the Bengkulu-Malay language can be expressed by using a reproach with sarcasm to mock. The use of satire in the society of Bengkulu-Malay is the form of the utterance which shows the local wisdom of Bengkulu-Malay society in expressing certain purpose in swearing (Andra, 2015 , p. 36). The data on number (4) Hahaha ...yo dak, lah cak ikan buntal naik ban (Hahaha, that person is like a puffer fish on a wheel). The sentence above is a swear in a form of phrase cak ikan buntal, like a puffer fish'. It is a swear because of disappointed then reproach to the hearer whose body like a puffer fish. The appearance of the puffer fish itself is round and plump.

The sentence on number (5) Nah, iko adonyo kucing air ko. Kemaren orang ke rumahnya. (There he is, the beaver! Yesterday, I went to his house) that has the swear in a form of phrase kucing air (beaver) is the reproach word with satire. It is happened because the speaker feels upset to the hearer who is considered as a person who betrayed his promise. The reference of kucing air (beaver) in the Bengkulu-Malay society is thought as an animal whose character always unfair and betray their promise.

The next reference to the animals is in the word lolak (seashells) which is for the Bengkulu-Malay society grouped to the sea animals in the same type with shells or sea-snails that have huge eyes and those eyes are edible for human. The phrase can be found on data number (6) Dasar mato lolak kau ko!. 'Dasar mata lolak (eng)kau ini!ee (what a bad eye sea shell you are). The speaker uses this phrase to express his disappointment to the hearer.

The swear which expresses the feeling of hatred refers to the freshwater animal is in the word bujuk (freshwater fish). It can be found in the data number (8) Bujuk kau! ,Bujuk (eng)kau! (you are a bad fresh-water fish). The phrase above refers to the hatred to the hearer who has the similarity to the freshwater fish which have a bad appearance moreover the fish is very greedy and bad too. 


\section{CONCLUSION}

The references of swear can be described as the imposition of the characteristic of human to the other creature except human, they are: animals, plants, or the other things else. The swear in a form of animal refers to the character or behavior of a person which is related to the animal. The form of references to the animals only exists on certain character of those animals which have the similarity to the person or situation which are being the target of swear. Not all of the animals can be used as the reference of swears.

The reference to the imposition of human characteristic to the animals in the data which have been found by the researcher shows that the swear which is used pointing and describing to the characteristic of human to the other non-human creature as the subject. The reference to the animal in swearing of Bengkulu-Malay language is the swear whose function is to express the anger, hatred, disappointment, or satire. The usage of swear with the animals as the reference is tend to be used by the speaker in young-ages.

Based on the result of the research, it shows that there are eight (8) kinds of swears which refer to the animal and morphologically have the form of word and phrases. They are: (1) bangsat (bedbugs); (2) anjing (dog); (3) babi (pig); (4) cak ikan buntal (puffer fish); and (5) kucing air (beaver); (6) Lolak (sea shells); (7) badak (rhinoceros); and (8) bujuk (fresh-water fish which have bad appearance).

\section{References}

Bloomfield, L. (1995). Bahasa. Diterjemahkan oleh I. Sutikno. Jakarta: PT.Gramedia Pustaka Utama.

Chaer, A. (2010). Kesantunan berbahasa. Jakarta: PT. Rineka Cipta.

Djajasudarma. T. F. (1993). Metode linguistik (ancangan metode penelitian dan kajian). PT. Eresco: Bandung. (2016). Metode penelitian linguistik. Fakulats Ilmu Budaya Universitas Padjadjaran: Bandung.

Djajasudarma, T. F. \& E. Citraresmana. (2016). Metodologi dan strategi penelitian linguistik. Fakultas Ilmu Budaya Unpad: Bandung.

Dynel, M. (2012). Swearing methodologically: the (im)politeness of expletivesin anonymous commentaries on youtube. Jurnal English Studies, 10, p. 25--50.

Fasya, M. dan E. Nicky. (2013). Variabel sosial sebagai penentu penggunaan makian dalam bahasa indonesia. Jurnal MLI, 31, (1), 81--102

Holmes, J. (2013). An introduction to sociolinguistics. Published Routledge: USA.

Kamus Besar bahasa Indonesia (Versi Daring). KBBI. http://www.kbbi.web.id. (2018, maret 15).

Kadir, A. R. (2004). Berbalas Pantun pada Acara Melamar Gadis. In S. S. dkk, Bunga Rampai Melayu Bengkulu (pp. 166-188). Bengkulu: Dinas Pariwisata Propinsi Bengkulu.

Kridalaksana, H. (2008). Kamus Linguistik. Gramedia Pustaka Utama: Jakarta.

Leech, G. (1993). Prinsip-prinsip pragmatik. (Diterjemahkan oleh M.D.D. Oka). Jakarta: UI Press.

1997. Semantik. (Diterjemahkan oleh Paina dan Soemitro). UNS Press: Semarang.

Ljung, M. (2011). Swearing (a cross-cultural linguistic study). New York: Palgrave Macmillan

Mahsun, M. S. (2014). Metode penelitian bahasa (tahapan strategi, metode, dan tekniknya. Rajawali Press: Jakarta.

Martono, N. (2015). Metode penelitian sosial (konsep-konsep kunci). Jakarta: Rajawali Pers.

Muhammad. (2011). Metode penelitian bahasa. Yogyakarta: Media.

Oliver, F. \& Elizabeth. (2011). Swearing and How to Deal with it in the Classroom, thesis. University of Iceland School of Education Studies: Iceland.

Rahardi, K. (2008). Pragmatik (kesantunan imperatif bahasa indonesia). Yogyakarta: Erlangga.

(2017). Linguistic Impoliteness in The Sociopragmatic Perspective. Jurnal Humaniora, Volume 29, No 3, 309--315.

Robin, \& Mercury, E. ( 1995). Swearing: A "Bad" Part of Language; A Good Part oflanguage learning. journaurevue tesl du canada 13 (1).

Rustinar, E., C Sobarna, Wahya, \& F. Djajasudarma. (2017). Fenomena Makian di Era Digital. Konferensi Nasional Sastra, Bahasa, dan Budaya (KS2B): Malang. 77--86.

(2017). Swear Bengkulu-Malay Language. IKAPROBSI kerjasama UNJ: Jakarta. 57--58.

(2017). Abuse Phrase in Bengkulu Malay Language. Jurnal Batra (Bahasa dan Sastra) Kantor Bahasa Bengkulu Volume: 3 No: 2 ISSN: 2460-6006. 135 -- 256.

(2018). Clitic -Lah in Constructing Swear of Bengkulu-Malay Language. Part of series ASSEHR Januari 2018 jilid 148. ICLA International Conference ( International Conference on Languages and Arts (ICLA 2017). https://www.atlantis-press.com: thompson reuters. 175 -- 179.

Salinger, J. D. (2002). Where have all the swearwords gone?. Faculty of Arts Department of English University of Helsinki: Helsinki.

Suandi, N. (2014). Sosiolinguistik. Yogyakarta: Graha Ilmu.

Susiyanto. (2005). Interaksi Antar Etnik dalam Kerangka Etnisitas. Disertasi. Unpad: Bandung. 
Trianto, A. (2004). Model Retorika Melayu: Pantun. In S. S. dkk, Bunga Rampai Melayu Bengkulu (pp. 191-213). Bengkulu: Dinas Pariwisata Propinsi Bengkulu.

Ullman, S. (2012). Pengantar semantik. Diterjemahkan oleh Sumarsono. Yogyakarta: Pustaka Pelajar.

Wijana, I. D. P. (2004). Makian dalam Bahasa Indonesia (Studi tentang Bentuk dan Referensinya). Jurnal Humaniora, $16(3), 242--251$. 